\title{
Testing the Compatibility of the Orthopedic Implants Material with the Recipient's Body in Arthroplastic Using Atomic Force Microscopy (AFM)
}

\author{
Boiko IV ${ }^{1}$, Zaft VB ${ }^{1 *}$, Lazarenko GO ${ }^{1}$, Lazarenko $\mathrm{OM}^{1}$, Aleksyeyeva $\mathrm{TA}^{2}$, Kartel $\mathrm{NT}^{2}$ and Lytvyn $\mathrm{PM}^{3}$ \\ ${ }^{1}$ Research and Practice Center of Preventive and Clinical Medicine, Ukraine \\ ${ }^{2}$ Chuiko Institute of Surface Chemistry, National Academy of Sciences of Ukraine, Ukraine \\ ${ }^{3}$ VE Lashkaryov Institute of Semiconductor Physics, National Academy of Sciences of Ukraine, Ukraine
}

Submission: April 30, 2018; Published: May 22, 2018

*Corresponding author: Vitalii Zaft, State Institution of Science "Research and Practice Center of Preventive and Clinical Medicine" State Administrative Department, Kyiv, Ukraine, Tel: +380965561481; Email: vzaft@ukr.net

\begin{abstract}
This article describes the method of preoperative testing of orthopedic implants material for compatibility with recipient's body by using Atomic Force Microscopy (AFM) and research the influence of tissue reactions on the implant's surface.
\end{abstract}

Keywords: Implants; Biocompatibility; Testing of material; Atomic force microscopy

\section{Introduction}

Every year orthopedic surgeons perform about 2,500,000 operation arthroplasty on various joints. In Europe in the past 5 years, the number of surgical operations in the endoprosthesis has increased by $80 \%$. Orthopedic doctors used the big spectra of implants which consist of (endoprotes of the thigh, knee, shoulder, elbow joint, joints on the ankles and even small joints of the feet and fingers). Unfortunately, each of these implants is foreign body for our organism. Rejection reaction or manifestation of hypersensitivity to the implant material is observed in $6-30 \%$ of cases of surgical intervention [115]. Immune reaction is one of the causes of complications of bone tissue on implants. The rejection reaction to the body on exogenous materials (implants) is manifested as a local aseptic inflammation with the formation of a fibro capsule around them, that leading to loss of their functional properties. The recipient organism reaction to foreign body depends on both branches of immune system, and particular importance to them has the absorption of immunoglobulins class G (IgG) and reaction of the body cells to surface of the implants [10].

Certain electron in homogeneity of the surface of materials plays the role of the binding centers of Ig and cells. Adhesion of IgG on surface of the implants provokes to the activation of the immune system, that leading to the development of persistent non-infectious (aseptic) inflammation. Material of implants that contact with the recipient organism determined by allocation of the last anti-inflammatory mediators like interleukin-1 and interleukin-6, which cause the process that can leads to selective dissolution of the components of implants and, in the future, it can cause to the destruction of implant. Selective dissolution of implants products can lead to toxic effects on cells, or stimulate synthesis of some proteins. Absorption or accumulation proteins of various toxic substances, protein complexes with nickel, chromium and cobalt ions, and formation around the material dense layer of the extracellular matrix, is important for the biological behavior of the material (attachment cells or bacteria to surface of materials).

Adhesion of proteins depends on the chemical properties of the material, and on its physical characteristics (wettability, superficial energy, etc.). Creating of expressive physical method for controlling of the compatibility of materials according is extremely necessary. In addition, the possibility of individual selection of materials, taking into account the immune status of the recipient organism, raises the problem of certification of materials to a qualitatively new level $[11,12,16]$. The purpose of study was determine the possibility of using Atomic Force Microscope (AFM) for predict the reaction of the organism to the implant (foreign body).

\section{Materials and Methods}

In newer present methods that are available for investigating internal and intermolecular forces acting between bimolecular. The AFM are the most effective research tool. This method covers 
a range of entropy forces in Femto-Newtons (1015 Newtons) for determine the force required to break covalent bonds in several nano-Newtons (10-9 Newtons). The Atomic Force Microscope (AFM), allows you to determine the strength of the interaction Antigen - Antibody and structure of individual macromolecules, such as DNA (intra-molecular forces) [16,17]. A wide range of controlled interactions creates real prerequisites for successful solving of a number of applied problems with the help of nanobiosensory technologies implemented on the hardware software basis of AFM. In recent years, have been made convincing attempts to use AFM for the diagnosis of cancer that based on the testing of the specific adhesion of IgG to malignant cells and their contact elasticity.

The AFM study of bioadhesive separation force was carried out on a scanning probe microscope Dimension 3000 NanoScopeIIIa (Veecocorp.) Both in air (at a temperature of $22 \mathrm{oC}$ and a relative humidity of $30 \%$ ) and in a liquid medium $(0.9 \%$ solution of sodium chloride). The velocity of the vertical movement of the probe selected in the range from 20 to 20,000 $\mathrm{nm} / \mathrm{sec}$. For measurements, used contact probes from SiNNDNP-20 (VeecoInc.) with V-shaped cantilever. The average radius of the edge of the probe $30 \mathrm{~nm}$, the cantilever's rigidity $0.06 \mathrm{~N}$ / $\mathrm{m}$. The control of the form of the tip performed before and after measurements using the "blind reconstruction" method using the test grid TGT-1 (NT-MDT). Clarification of the value of the cantilever hardness was carried out by analyzing the spectrum of its temperature noise.

The scheme of measurements is presented in Figure 1. At the initial moment, the probe modified by the antibody (AT) is far from the surface of the sample (point 1 ) and the interaction surface of the surface-AT is zero. Next, the AFM system of vertical movement of the probe leads the probe to the surface, controlling the distance to the accuracy of the angstrom (10-10 $\mathrm{m})$. At a certain minimum distance between the probe and the surface, the "capture" of the modified probe is carried out by the surface under the action of the attraction forces (point 2). With further approximation of the probe and the surface begins to act repulsive forces that prevent the penetration of the probe into the surface. After reaching the maximum value of the repulsion force given by the operator based on the conditions of the experiment (point 3) begins the inverse vertical movement of the probe. At the same time, the surplus of all the forces holding the modified probe near the surface is balanced by the force of elastic deformation of the probe console at the point 4, in which there is a separation from the surface. Thus, the maximum value of the force of the bioadgezial interaction corresponds to the magnitude of the detachment force of the probe from the surface (point 4), which is equal to the strength of the elastic deformation of the probe console, measured by the detection system of the AFM, by the value of its deflection d (Figure 1).

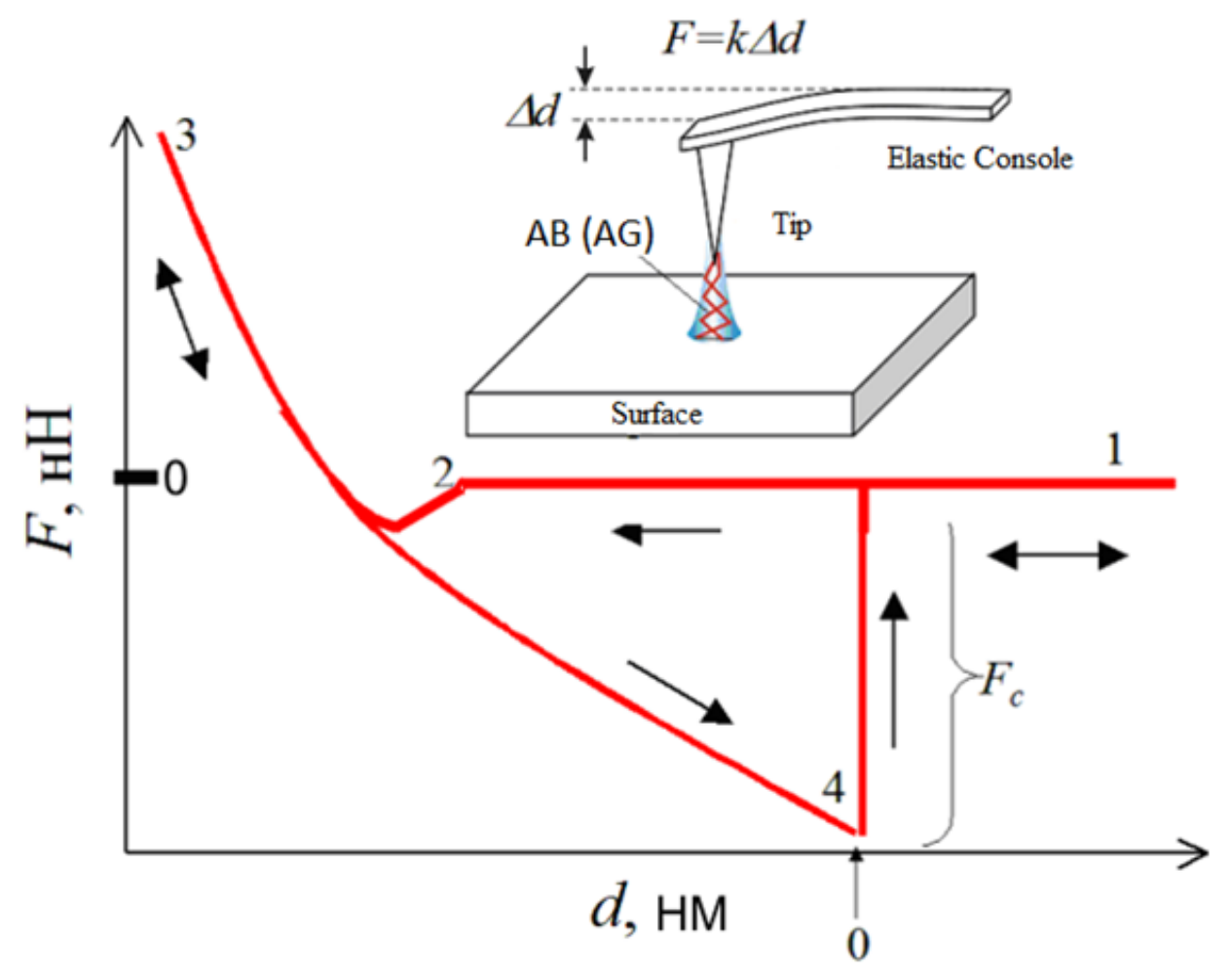

Figure 1: Scheme of measurements of the force of separation F by the AFM method. The strength of bioadhesion is determined from the measured AFM by the value of the elastic deformation of the probe console $\Delta d$ as $F=k \Delta d$, where $k$ is the elastic constant console. 
For modified of the surfaces of probe were applied antibodies. As antibodies used total IgG, which were isolated from the serum of the patient's blood. $\mathrm{AB}$ was applied to the ACM with a solution at a concentration of $0.1 \mu \mathrm{g} / \mathrm{ml}$. $(0.9 \%$ $\mathrm{NaCl}$ solution). The measurements were carried out both in air and in water, in order to check the difference between the data obtained, whether they are essential for the evaluation of the bioadhesion forces. During measurements in the atmosphere on the surface of the sample due to the presence of capillary forces, a so-called capillary bridge is formed, which makes a significant contribution to the amount of adhesive forces. Thus, the value of separation strength when measured in the air is greater than during measurements in water. However, as it has been established, qualitative correlations between the values of the separation forces for different samples are retained. In clinical trials included patients, with joint diseases, that in future will have arthroplasty according to treatment protocols.

In the perioperative period, sampling of $5 \mathrm{ml}$ of patient's venous blood is performed in vacuum container, from which was prepared serum, according to the standard method, was isolated total IgG [18]. After purification and dilution, an appropriate concentration of IgG, $2 \mu \mathrm{g} / \mathrm{ml}$, is applied to the AFM probe. The probes with the applied IgG patient were tested for the compatibility of the implant material with the patient's body. The value of the confinement of probe with IgG of recipient to the surface of the implant was considered to evaluate the compatibility of the material with the patient's body. The higher value of the strength retention, more likely development of the reaction of implant rejection by the organism. The basis for the hip implant was the titanium alloy Ti6Al4V, the characteristics of which are given in Table 1.

Table 1: The physical characteristics of the alloy hip implant bases.

\begin{tabular}{|c|c|c|c|c|}
\hline Material & Method of processing & Young modulus & Compressive strength & Tensile strength \\
\hline Ti6Al4V & Cold & $100-110$ & $830-1070$ & $9200-1140$ \\
\hline
\end{tabular}

\section{Results}

For the period 2015-2016, in the clinic of the State Institution of Science "Research and Practice Center of Preventive and Clinical Medicine" State Administrative Department, was performed a test of the compatibility of the material of orthopedic implants in endoprosthetics of large joints with the recipient organism with the help of AFM in 11 patients $[13,18]$. Patients underwent surgical intervention (arthroplasty of the hip and knee joints). In Table 2 show the strength of the IgG surface of the prosthetic element. The force of confinement clean probe with the surface of the implant ranged from 5-8 $\mathrm{nN}$. Thus, according to the AFM, one can confidently say that in all cases the recipient develops a local aseptic inflammation at the site of the implant. Reliability of the obtained values $p \leq 0,005$. Listed in Table 3 data suggest that in the course of time, the patient only increases the CRP and the number of segmental neutrophils. And the results of testing with AFM remain at $49-56 \mathrm{nN}$, which testify to the constant reaction of the organism to the implant. So the stress of immune system of this patient is constantly maintained by the presence of the implant, and the specificity of IgG to the prosthesis remains very high.

Table 2: Significance of the level of C-reactive protein (CRP), clinical parameters of the blood formula, IgG concentration in the serum and data of force of confinement of the surface of the titanium sample of the IgG patient, $F$.

\begin{tabular}{|c|c|c|c|c|c|c|}
\hline No & $\begin{array}{c}\text { CRP } \\
(0-5 \mathrm{mg} / \mathrm{l})\end{array}$ & $\begin{array}{c}\text { S/n \% } \\
(47-72 \%)\end{array}$ & $\begin{array}{c}\text { Lym \% } \\
(19-37 \%)\end{array}$ & $\begin{array}{c}\text { Mon.\% } \\
(3-10 \%) \\
\end{array}$ & $\begin{array}{c}\text { IgG, g/l } \\
(5,5-18,5 \mathrm{~g} / \mathrm{l})\end{array}$ & $\begin{array}{c}\text { AFM F, nN } \\
(5-8 \mathrm{nN})\end{array}$ \\
\hline 1 & 39,1 & 42,0 & 43,0 & 7 & 8,8 & 51,8 \\
\hline 2 & 34,5 & 68,0 & 23,0 & 5 & 6,4 & 48,7 \\
\hline 3 & 9,3 & 69,0 & 22,5 & 5 & 6,7 & 49,6 \\
\hline 4 & 5 & 58,0 & 31,2 & 4 & 7,1 & 50,1 \\
\hline 5 & 4,5 & 46,0 & 30,0 & 6 & 5,1 & 34,1 \\
\hline 6 & 3,1 & 66,0 & 31,7 & 4 & 11,2 & 56,3 \\
\hline 7 & 43,8 & 66,0 & 18,5 & 3 & 8,6 & 52,0 \\
\hline 8 & 5.5 & 67,0 & 41,2 & 5 & 5,3 & 38.1 \\
\hline 9 & 2.1 & 50,0 & 28,2 & 4 & 5,1 & 29.8 \\
\hline 10 & 4,4 & 48,0 & 29,3 & 1 & 6,2 & 33.0 \\
\hline 11 & 25.5 & 61,0 & 30,7 & 3 & 7,1 & 32.7 \\
\hline
\end{tabular}




\section{Juniper Online Journal of Orthoplastic \& Microsurgical Reconstruction}

Table 3: The value of CRP, clinical parameters of the blood formula, serum IgG concentrations, and $F$ data of force of confinement of the surface of the titanium sample of IgG patient No. 6 .

\begin{tabular}{|c|c|c|c|c|c|c|}
\hline & $\begin{array}{c}\text { CRP } \\
(0-5 \mathrm{mg} / \mathrm{l})\end{array}$ & $\begin{array}{c}\text { S/n \% } \\
(47-72 \%)\end{array}$ & $\begin{array}{c}\text { Lym \% } \\
(19-37 \%)\end{array}$ & $\begin{array}{c}\text { Mon.\% } \\
(3-10 \%)\end{array}$ & $\begin{array}{c}\text { IgG, g/l } \\
(5,5-18,5 \mathrm{~g} / \mathrm{l})\end{array}$ & $\begin{array}{c}\text { AFM F, nN } \\
(5-8 \mathrm{nN})\end{array}$ \\
\hline Before operation & 3,1 & 66,0 & 31,2 & 4 & 7,8 & 56,3 \\
\hline $\begin{array}{c}14 \text { days after } \\
\text { operation }\end{array}$ & 5 & 58,1 & 30,4 & 4 & 7,9 & 50,1 \\
\hline $\begin{array}{l}1 \text { month after } \\
\text { operation }\end{array}$ & 34,5 & 68,2 & 23,2 & 5 & 11,2 & 48,7 \\
\hline $\begin{array}{l}4 \text { month after } \\
\text { operation }\end{array}$ & 39,1 & 68,0 & 43,1 & 7 & 14,3 & 51,8 \\
\hline
\end{tabular}

\section{Discussion}

The variety of the reaction of the receptor's tissues to the foreign body that is introduced into the body depends on its immune status and the primary reaction of the cells of the body to the surface of the implants is of particular importance [14]. The development of modern high-tech branches of medicine, including orthopedics, traumatology and dentistry, places high demands on the quality of implantable materials. The main of them - medical and biological, based on the absence of toxic, carcinogenic and corrosive properties in the material Biomaterials should be biocompatible and have the technological qualities that allow, in the case of a certain treatment, to obtain the necessary structure that is characterized by frictional stability and low thermal conductivity $[15,19]$. At the same time, implant materials should perform not only substitution function, but gradually integrate into the surrounding bone, promote the formation and remodeling of bone tissue.

Scientific evidence suggests that activation of developments in the creation of new and improved known biomaterials for medicine $[10,11,17]$. It should be noted that even a minor modification of the biomaterial (elemental composition, phase state, topography and surface structure, etc.) can significantly alter its properties. Therefore, the medical-biological research of artificial biomaterials remains relevant and significant $[15,17]$. An approach developed to solve the problem of individual prediction of the degree of compatibility of implant materials with the recipient organism on the basis of nanobiosensors controlled by the AFM hardware and software system is appropriate and relevant. Today, the development of optimal conditions for nanobiosensory testing of implants with AFM and the study of the effects of reactions of tissues of the recipient on the surface of implants will significantly increase the effectiveness of surgical treatment of diseases of the locomotor system by selecting / selecting optimally compatible implants with the recipient organism $[8,9,17,20]$.

\section{Conclusions}

Development of optimal conditions for testing the implant with the body of the recipient using Atomic Force Microscopy (AFM) will significantly increase the effectiveness of surgical treatment of orthopedic disorders.
The method of testing the compatibility of the implant material with the recipient's body using AFM can allow:

a. At the preoperative stage, determine the possibility of occurrence of processes of rejection of the implant.

b. Provide compatibility with body implants and choose the most appropriate and / or to provide drugs to prevent rejection.

c. Data received through research, allow the doctor to choose the necessary tactics of patients in the postoperative period.

\section{References}

1. Hallab NJ, Merritt K, Jacobs JJ (2001) Metal sensitivity in patients with orthopedic implants. J Bone Joint Surg Am 83-A(3): 428-436.

2. Jacobs JJ, Roebuck KA, Archibeck M, Hallab NJ, Glant TT (2001) Osteolysis: basic science. Clin Orthop Relat Res 393: 71-77.

3. Major MR, Wong VW, Nelson ER, Longaker MT, Gurtner GC (2015) The foreign body response: At the interface of surgery and bioengineering. Plast Reconstr Surg 135(5): 1489-1498.

4. Thyssen JP, Jakobsen SS, Engkilde K, Johansen JD, Soballe K, et al. (2009) The association between metal allergy, total hip arthroplasty, and revision. Acta Orthop 80(6): 646-652.

5. Willert HG, Buchorn GH, Fayyazi A, Flury R, Windler M, et al. (2005) Metal-on-metal bearings and hypersensitivity in patients with artificial hip joints. A clinical and histomorphological study. J Bone Joint Surg Am 87(1): 28-36.

6. Zeng Y, Feng W (2013) Metal allergy in patients with total hip replacement: a review. J Int Med Res.

7. Anderson JM, Rodriguez A, Chang DT (2008) Foreign body reaction to biomaterials. Seminars in Immunology 20(2): 86-100.

8. Buddy Ratner, Allan Hoffman, Frederick Schoen, Jack Lemons (2004) Biomaterials Science: An Introduction to Materials in Medicine 2nd Edition Elsevier Academic Press.

9. Patel NR, Gohil PP (2012) A review on biomaterials: scope, applications \& human anatomy significance. International Journal of Emerging Technology and Advanced Engineering 2(4): 91-101.

10. NA Korzh, SV Malyshkina, LA Kladchenko, IB Timchenko (2005) Implantatsionnye materialy i osteogenez. Rol' biologicheskoy fiksatsii i osteointegratsii v rekonstruktsii kosti. Ortoped travmatol 4: 118-127.

11. Malishkina SV (2006) Biosumisnist' ta tsitotoksichnist' kompozitu na osnovi polilaktitu p. 47-50.

12. TA Alekseeva, IS Ermolenko, NI Lebovka, PM Litvin, SP Oshkaderov, et al. (2009) Issledovanie bioadgezivnykh vzaimodeystviy na zolote, 
kremnii i stekle metodom atomno-silovoy spektroskopii. Metallofizika i noveyshie tekhnologii tom 31(2): 241-248.

13. Kartel TM, Litvin PM, Alekseeva TA, Lazarenko GO, Lazarenko OM (2015) Klinichne zastosuvannya testuvannya khirurgichnikh implantativ na biosumisnist' z organizmom retsipiєnta. Metodichni rekomendatsiï Vidavets Yu V Picha “Karavela” Kiïv S 32.

14. Sebastian Bauer, Patrik Schmuki, Klaus von der Mark, Jung Park (2013) Engineering biocompatible implant surfaces. Part I: Materials and surfaces. Progress in Materials Science 58(3): 261-326.

15. DuguyN (2000) Biomaterials and osseous regeneration. Ann Chir Plast Esthet 45(3): 364-376.

16. TA Alekseeva, IS Ermolenko, SP Oshkaderov, ON Lazarenko (2009) Izmenenie poverkhnosti metallicheskikhimplantov s neorganicheskimi pokrytiyami posle nakhozhdeniya v zhivom organizme. Metallofizika i noveyshie tekhnologii tom 31(7): 979-988
17. Alekseeva TA, Vinichenko NP, Galich SP, Lazarenko ON, Litvin PM (2012) i dr Novye nanotekhnologii v meditsyne Ukrainy K 56-82;167$177 ; 184$.

18. Lazarenko GO, Lazarenko OM (2009) Sposib individualnogo testuvannya implantatu na sumisnist' $\mathrm{z}$ organizmom retsipienta. Patent Ukraïni Byul 13: S8.

19. P Linez Bataillon, F Monchau, M Bigerelle, M Hildebrand (2002) In vitro MC3T3 osteoblast adhesion with respect to surface roughness ofTi6Al4V substrates. Biomolecular Engineering 19(2-6): 133-141.

20. Park YS, Moon YW, Lim SJ, Yang JM, Ahn G, et al. (2005) Early osteolysis following second-generation metal-on-metal hip replacement. J Bone Joint Surg Am 87(7): 1515-1521.

\section{Your next submission with Juniper Publishers} will reach you the below assets

- Quality Editorial service

- Swift Peer Review

- Reprints availability

- E-prints Service

- Manuscript Podcast for convenient understanding

- Global attainment for your research

- Manuscript accessibility in different formats (Pdf, E-pub, Full Text, Audio)

- Unceasing customer service

Track the below URL for one-step submission https://juniperpublishers.com/online-submission.php 